\title{
Mantle upwellings, melt migration and the rifting of Africa: insights from seismic anisotropy
}

\author{
J.-M. KENDALL ${ }^{1}$, S. PILIDOU ${ }^{2}$, D. KEIR ${ }^{3}$, 1.D. BASTOW ${ }^{2}$, G.W. STUART ${ }^{2}$ \& A. AYELE \\ ${ }^{1}$ Department of Earth Sciences, University of Bristol, Wills Memorial Building, \\ Queen's Road, Bristol, BS8 1RJ, UK (e-mail: gljmk@bristol.ac.uk) \\ ${ }^{2}$ School of Earth and Environment, Institute of Geophysics and Tectonics, University of Leeds, \\ Leeds, LS2 9JT, UK \\ ${ }^{3}$ Department of Geology, Royal Holloway, University of London, Egham, Surrey, \\ TW2O OEX, UK \\ ${ }^{4}$ Geophysical Observatory, Addis Ababa University, Addis Ababa, PO Box 1176, Ethiopia
}

\begin{abstract}
The rifting of continents and eventual formation of ocean basins is a fundamental component of plate tectonics, yet the mechanism for break-up is poorly understood. The East African Rift System (EARS) is an ideal place to study this process as it captures the initiation of a rift in the south through to incipient oceanic spreading in north-eastern Ethiopia. Measurements of seismic anisotropy can be used to test models of rifting. Here we summarize observations of anisotropy beneath the EARS from local and teleseismic body-waves and azimuthal variations in surfacewave velocities. Special attention is given to the Ethiopian part of the rift where the recent EAGLE project has provided a detailed image of anisotropy in the portion of the Ethiopian Rift that spans the transition from continental rifting to incipient oceanic spreading. Analyses of regional surface-waves show sub-lithospheric fast shear-waves coherently oriented in a northeastward direction from southern Kenya to the Red Sea. This parallels the trend of the deeper African superplume, which originates at the core-mantle boundary beneath southern Africa and rises towards the base of the lithosphere beneath Afar. The pattern of shear-wave anisotropy is more variable above depths of $150 \mathrm{~km}$. Analyses of splitting in teleseismic phases (SKS) and local shear-waves within the rift valley consistently show rift-parallel orientations. The magnitude of the splitting correlates with the degree of magmatism and the polarizations of the shear-waves align with magmatic segmentation along the rift valley. Analysis of surface-wave propagation across the rift valley confirms that anisotropy in the uppermost $75 \mathrm{~km}$ is primarily due to melt alignment. Away from the rift valley, the anisotropy agrees reasonably well with the pre-existing Pan-African lithospheric fabric. An exception is the region beneath the Ethiopian plateau, where the anisotropy is variable and may correspond to pre-existing fabric and ongoing melt-migration processes. These observations support models of magma-assisted rifting, rather than those of simple mechanical stretching. Upwellings, which most probably originate from the larger superplume, thermally erode the lithosphere along sites of pre-existing weaknesses or topographic highs. Decompression leads to magmatism and dyke injection that weaken the lithosphere enough for rifting and the strain appears to be localized to plate boundaries, rather than wider zones of deformation.
\end{abstract}

The $3000 \mathrm{~km}$-long East Africa Rift System (EARS) is a striking feature of the African continent (Fig. 1). The EARS marks the separation of the Nubian and Somalian plates and the possible isolation of smaller micropates (Calais et al., this volume). In the north, it becomes an arm of a rift-rift-rift triple junction with the Gulf of Aden and Red Sea rifts. The formation of ocean basins through continental rifting is a fundamental feature of plate tectonics, yet the mechanism for break-up is poorly understood. The EARS is unique in that it captures each stage of the evolution of such a basin, from the birth of a rift in Tanzania. to the transition from continental rift to incipient oceanic spreading centre in northern Ethiopia (e.g. Ebinger \& Casey 2001).

Another prominent feature of the African continent is its elevation and dynamic topography, which are due to deep-seated mantle upwelling beneath the continent (Davies 1998). The Atrican superplume is one of two large-scale low-velocity anomalies that are clearly visible in the degreetwo component of tomographic images of the mantle (the other lies beneath the southern Pacific Ocean). This low-velocity anomaly originates at the core-mantle boundary beneath southern 


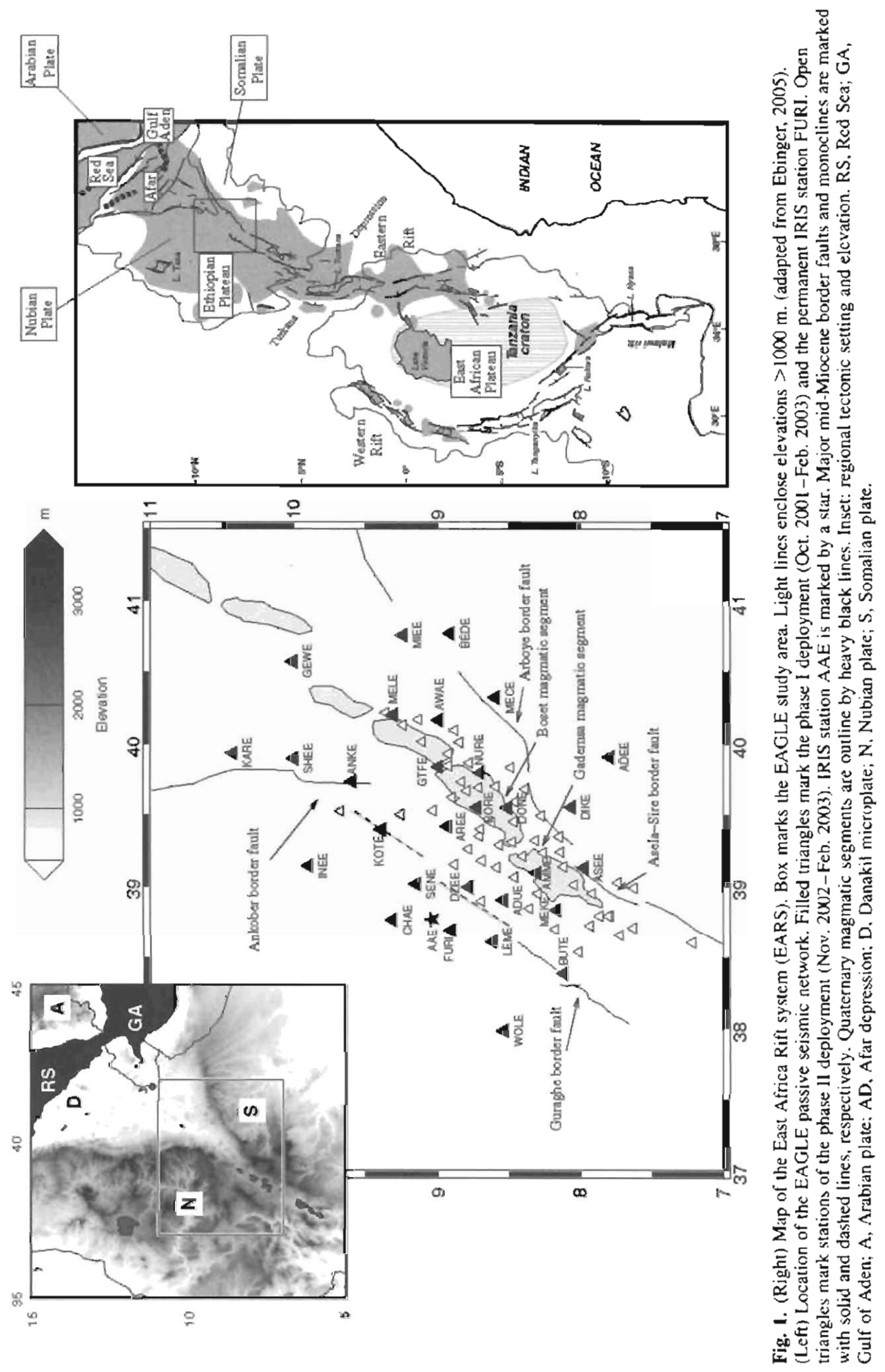


Africa, and rises in a north-northeastward direction (Ritsema et al. 1999), producing the African superswell (Nyblade \& Robinson 1994). This buoys up Africa and the southwestern flank of Arabia (Lithyow-Bertelloni \& Silver 1998; Gurnis et al. 2000; Daradich et al. 2003).

The connection between the African superplume/ superswell and the EARS is unclear. Global tomography shows plume-like features extending into the lower nuantle beneath the Afar region of Ethiopia, but its connection to the superplume is not well defined (compare, for example, models of Montelli et al. 2004 and Ritsema et al. 1999). Regional tomography shows a thin tabular lowvelocity zone to depths of over $250 \mathrm{~km}$ beneath the continental part of the Ethiopian rift (Bastow et al. 2(005). This anomaly broadens laterally in the more oceanic northeasterly region and appears to connect with the Afar plume (Benoit et al. 20(0)3; Debayle ef al. 2001). There are also numerous lines of evidence for a separate plume or upper-mantle instability under Tanzania or Uganda (Ebinger \& Sleep 1998; Nyblade et al. 2000; Weeraratne et al. 2003), but its depth extent is unclear. The northsouth propagation of volcanism and rifting, and general NNW movement of Nubia, suggest that the Tanzanian plume may have originally impacted beneath SW Ethiopia (George et al. 1998; Courtillot et al. 1999). However, this may be part of a larger single plume (Ebinger \& Sleep 1998; Furman et al. this volume).

The driving forces for continental rifting come from distant plate forces (e.g. subduction), tractions imposed on the base of the plate due to underlying mantle convection, and forces associated with asthenospheric upwelling beneath the plate (e.g. smallscale convection or plumes) (Ebinger 2005). The perhaps simplest model of rifting involves mechanical stretching, where strain is accommodated by large offset border faults (McKenzie 1978). Such a mechanism requires large stresses in order to rupture cold, thick lithosphere. Alternatively, plume-lithosphere interactions may heat the lithosphere enough to promote magma production and more easily facilitate rifting of the consequently weakened lithosphere (Buck 2004). In the southern part of the EARS, where the rift is young, the strain is more predominantly accommodated by border faults, whilst in northeastern Ethiopia, where occanic spreading is starting, the strain is largely accommodated by magma injection along segments in the rift valley (Ebinger \& Casey 2001 ; Keranen et al. 2004). It is estimated that nearly $80 \%$ of the strain in the crust is localized to the magmatic segments (Bilham et al. 1999).

Seismic methods offer a means of testing such models of rifting. Tomography can be used to map the structure of low-velocity anomalies and hence the morphology of warm mantle upwellings beneath rifts (e.g. Evans \& Achauer 1993). Additionally, measurements of scismic anisotropy can be used to infer patterns of strain and flow (Vauchez et al. 2000). The anisotropy can be due to the lattice-preferred orientation (LPO) of crystals or the preferred orientation of inclusions (e.g. oriented melt pockets (OMP)) or periodic thin layering (PTL) of contrasting materials (e.g. Kendall 2000 ). The resulting rock fabric produces a directional dependence in seismic velocities, or, in other words, seismic anisotropy. Here we use observations of anisotropy on a range of length scales to test models of rifting with the aim of achieving a better understanding of the connection between large-scale mantle flow and ocean basin formation.

There are a number of seismic methods for measuring anisotropy in the mantle (e.g. see Kendall 2000). The observation of two independent, orthogonally polarized shear-waves is perhaps the most unambiguous indicator of wave propagation through anisotropic media. A shearwave in an isotropic medium will split into two shear-waves when it encounters an anisotropic medium. The orientation of the shear-waves and their difference in travel-times constrain the symmetry and magnitude of the anisotropy. Shearwave splitting measured in teleseismic core phases such as SKS is routinely used to measure upper-mantle anisotropy (for review, see Savage 1999). Using networks or arrays of seismic stations, SKS splitting measurements offer good lateral resolution of anisotropy, but poor vertical resolution. Analyses of splitting in local events, if available, can be used to provide depth constraints on the extent and magnitude of the anisotropy.

Seismic anisotropy also affects surface-waves. It leads to azimuthal variations in surface-wave phase velocities, discrepancies between Love-wave and Rayleigh-wave-derived shear-wave velocity models, and particle motion anomalies (Kirkwood \& Crampin 1981). The dispersive nature of surface-wave propagation leads to good resolution of anisotropy variation with depth, but long wavelengths mean poor horizontal resolution. The analysis of anisotropy using a combination of seismic body- and surface-waves provides good vertical and horizontal resolution and offers information about length scales of anisotropy.

Here we summarize observations of seismic anisotropy beneath the EARS. Special detail is given to the Ethiopian part of the rift, where we have detailed coverage from data acquired during the EAGLE (Ethiopia Afar Geoscientific Lithospheric Experiment) project (Maguire et al. 2003). After a review of anisotropy mechanisms, we start with the regional picture from teleseismic surface-wave analyses and 
progress to increasingly finer resolution beneath the Northern Main Ethiopian Rift (NMER).

\section{Mechanisms for seismic anisotropy (LPO vs. OMP)}

The primary mechanism for seismic anisotropy in the upper mantle is the lattice-preferred orientation of olivine (and to a lesser extent enstatite) crystals in peridotites. Experimental measurements (Nicholas \& Christensen 1987; Ben Ismail \& Mainprice 1998) and numerical simulations (Blackman et al. 1996; Tommasi 1998) show that the $a$-axis [100] of olivine crystals will align in the flow direction. This is most effective when the rock is deforming by dislocation creep. which is controlled by strain rate and history, grain size, temperature and fluid content. There is some variability in the magnitude of anisotropy observed in xenoliths of peridotite, but it is on average $5 \%$ (Ben Ismail \& Mainprice 1987). In general, such polycrystal rocks have triclinic elastic symmetry, but with peridotites this can be well-approximated with an orthorhombic symmetry (Blackman \& Kendall 2002). Anisotropy is often observed to decrease beneath $220 \mathrm{~km}$ (e.g. Montagner 1994). This may be due to a transition from dislocation to diffusion creep, which is less effective in producing LPO (Karato 1992). More recently, it has been proposed that at high pressures the dominant slip direction in olivine changes to the c-axis [001], which produces little aggregate anisotropy (Mainprice et al. 2005).

Figure 2 a shows $P$-wave and $S$-wave velocities as a function of propagation direction for a peridotite from Tanzanian upper-mantle xenoliths (Vauchez et al. 2005). P-wave velocities are fastest in the How direction, whilst shear-wave splitting is minimal for $\mathrm{S}$-wave propagation in the flow direction. With a horizontal flow direction and a vertical flow plane, a near-vertically propagating shearwave (c.g. SKS) will show large amounts of shear-wave splitting and the fast shear-wave will be polarized in the direction of flow. The amount of SKS splitting will be much less for a horizontal flow plane. Assuming horizontal flow and horizontal wave propagation, the largest shear-wave splitting will occur in directions near normal to the flow direction and horizontally polarized shearwaves (Sh) will be faster than vertically polarized shear-waves (Sv); consequently, Love-wave analyses will yield faster shcar-wave models than those derived from Rayleigh waves. LoveRayleigh models will be much more similar for surface-waves propagating in the flow direction.

The preferred alignment of inclusions will also produce a long-wavelength anisotropy, provided the periodicity of the inclusions is much shorter than the seismic wavelength. In contrast, LPO is a more intrinsic cause of anisotropy and will not be seismic-wavelength dependent. Microcracks vertically oriented parallel to the direction of maximum horizontal stress are thought to be the main cause of anisotropy in the shallow crust (Crampin 1994). The resulting style of anisotropy is often referred to as azimuthal anisotropy as it produces azimuthal variations in velocities, and is often approximated by hexagonal symmetry with a horizontal symmetry axis or horizontal transverse isotropy (HTI). Alternatively, PTL of materials with contrasting velocities (e.g. volcanics and sediments) can be very effective in generating Iong-wavelength anisotropy (Backus 1962). If the layering is horizontal, the medium will act like a homogeneous hexagonally symmetric material with a vertical symmetry axis. This is commonly referred to as vertical transverse isotropy (VTI), but the terms polar or radial anisotropy are aiso often used to describe such symmetry. A characteristic of such media is a lack of azimuthal variation in velocities and a lack of shear-wave splitting in vertically travelling shear-waves.

The preferred alignment of melt inclusions is a very effective way to generate anisotropy (Kendall 1994). The magnitude of the anisotropy is not only very sensitive to the volume fraction of the melt, but also the shape of the melt inclusions. Thin disk-like inclusions are more effective at generating anisotropy than long tube-shaped inclusions (Kendall 2000). Spherical melt pockets are obviously the least-effective shapes for gencrating anisotropy. The shape and orientation of melt is controlled by wetting angles and strains in the medium (Schmeling 1985; Faul et al. 1994). As strain and melt fraction increases, the melt will start to align along grain edges and then crystal faces.

Figure $2 \mathrm{~b}$ shows $\mathbf{P}$ - and $\mathrm{S}$-wave velocities in a medium with vertically oriented melt pockets (OMP) that are tabular and disk-like in shape. $P$-wave velocities are highest for wave propagation parallel to the melt pockets, and shear-wave splitting is largest in these directions. For directions of horizontal wave propagation parallel to the OMP. vertically polarized shear-waves $(\mathrm{Sv})$ are faster than horizontally polarized shear-waves (Sh). With surface waves, Love waves would produce a slower shear-wave model than that derived from Rayleigh waves. No shear-wave splitling occurs when waves propagate in a direction normal to the flat face of the inclusion. These predictions are sensitive to the inclusion aspect ratio, but they are most sensitive to the shape of the inclusion and the material in the inclusion. For example, flat oblate inclusions of melt are much more effective 
(a)
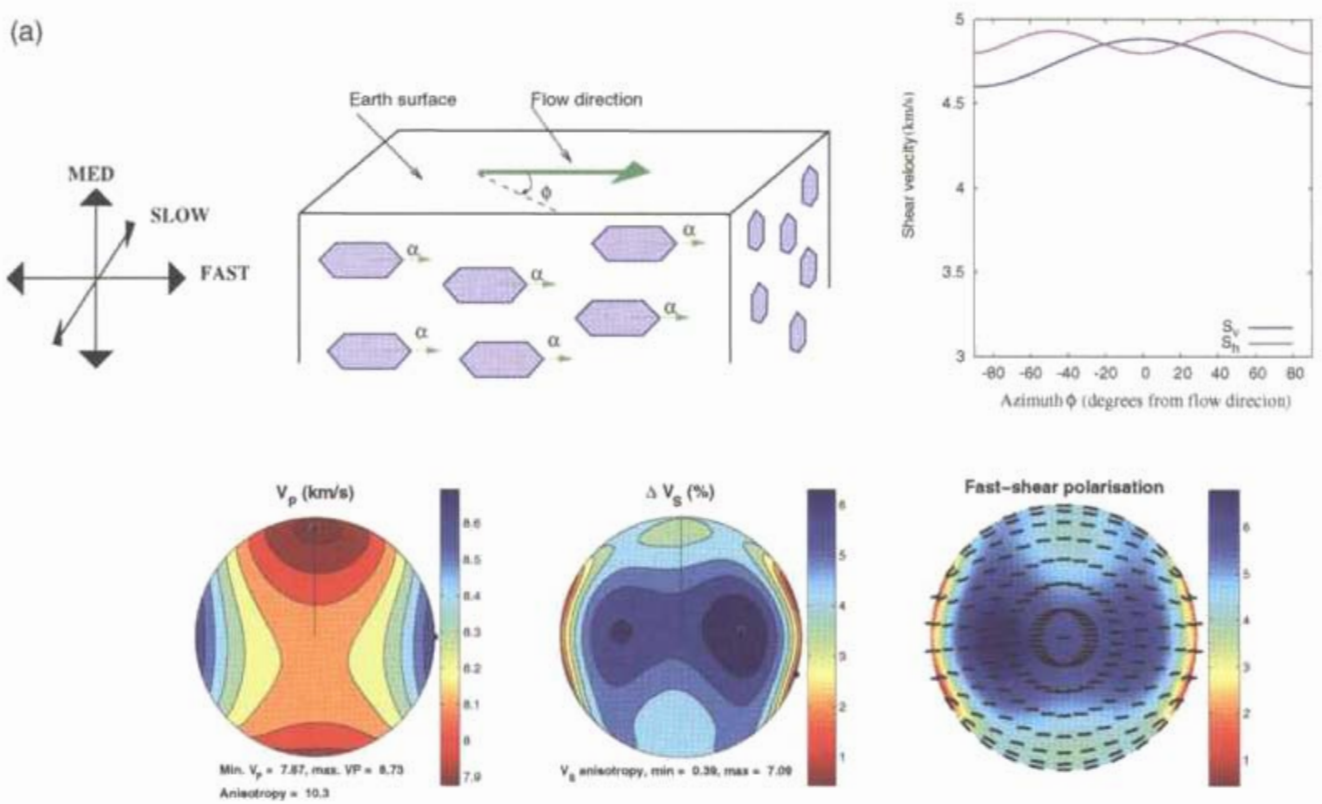

(b)
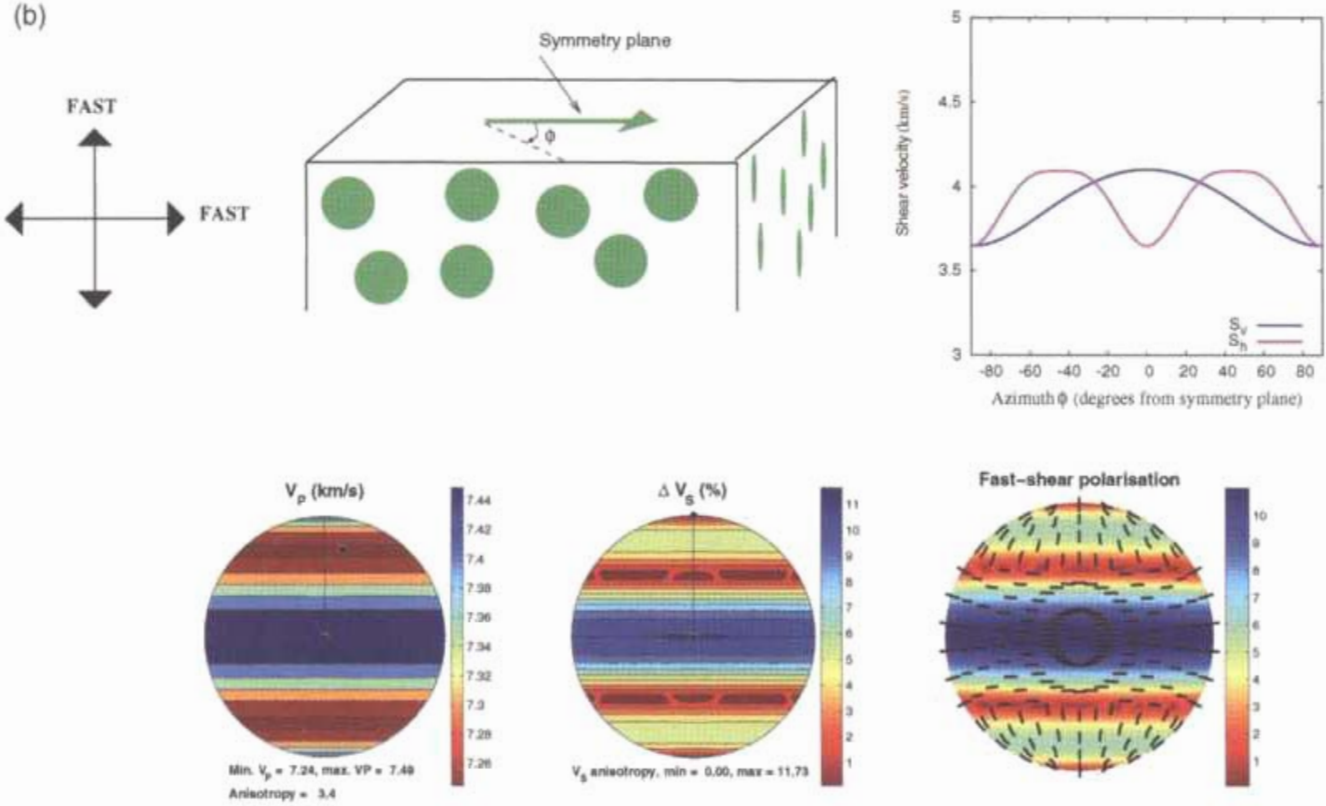

Fig. 2. Mechanisms for seismic anisotropy. (a) Anisotropy due LPO of upper-mantle minerals. Top left shows directions of fast, slow and medium P-wave velocities, assuming a horizontal flow direction and a vertical flow plane as shown in middle cartoon. Top right shows azimuthal variations in vertically and horizontally polarized shear-waves (Sv vs. Sh). Velocities are those determined for a peridotite from a Labait xenolith, Tanzania (Vauchez et al. 2005). Lowerhemisphere pole figures show seismic velocities: P-wave anisotropy is shown at left, \% S-wave splitting is shown in middle, and the right shows polarization of fast shear-waves superimposed over S-wave splitting contours. Flow direction is to the right, the flow plane is vertical and the vertical direction is the centre of pole figure. (b) Anisotropy due to OMP. Melt-induced anisotropy is modelled using the theory of Tandon \& Weng (1984) (e.g. see Kendall 2000). Melt volume fraction is assumed to be $0.1 \%$ and the melt lies in disk-like in pockets (oblate spheroids) with an aspect ratio of 0.02 . 
in generating anisotropy than prolate inclusions of high-velocity material. A further discussion of anisotropy sensitivity to inclusion shape and material can be found in Blackman \& Kendall (1997) and Kendall (2000).

These diagnostics of wave propagation in various styles of anisotropy can be used to help guide interpretations of the cause of anisotropy.

\section{Regional patterns of surface-wave anisotropy}

A large-scale picture of upper-mantle anisotropy can be derived from observations of azimuthal variations in surface-wave phase velocities. For example, Hadiouche et al. (1989) derived anisotropy models for Africa, noting a general northsouth trend in the fastest direction for $40-100 \mathrm{sec}$ Rayleigh waves in eastern Africa.

More recently, Debayle et al. (2005) have constructed a high-resolution, 3D tomographic model for the shear-wave velocity and azimuthal anisotropy of the African upper mantle. Their model resulted from the analysis of 9000 multimode (fundamental and first three higher modes) Rayleigh waveforms from 1022 regional earthquakes recorded at 250 stations. To construct the model, they first obtained path-averaged Sv-velocity models that best predicted the observations. Periods of 50-160 sec were used and path lengths ranged from $1000 \mathrm{~km}$ to $10000 \mathrm{~km}$. The path-average models were then inverted for horizontal variations in shear-velocity and azimuthal anisotropy at different depths. Tests showed that a few hundred kilometres of lateral resolution and $40-50 \mathrm{~km}$ vertical resolution is achieved in the top $400 \mathrm{~km}$ of the mantle.

Figure 3 shows depth slices from the Debayle et al. (2005) model centred on Ethiopia. Diffuse low-velocity zones lie beneath Afar and the Ethiopian plateau, and are in general agreement with recent body-wave travel-time tomography models (Montelli et al. 2004; Bastow et al. 2005; Benoit et al. 2006). These results are also similar to recent surface-wave results of Sebai et al. (2006).

Within the lithosphere or upper $150 \mathrm{~km}$, the anisotropy shows clear differences between the Nubian plate and Somalian plate. The anisotropy orientation varies with depth between $\mathrm{SF}-\mathrm{NW}$ and cast-west beneath the Ethiopian plateau. The trend in the upper $75 \mathrm{~km}$ agrees with the orientation of major faults and Mesozoic rift structures (Moore \& Davidson 1978; Berhe 1990). The orientation in the underlying lithosphere aligns with an east-west trending suture (Stern et al. 1990), the interpretation of which is somewhat controversial (Church et al. 1991). Both directions are different from
Pan-African north-south structural trends (Berhe 1990; Abdelselam \& Stern 1996). However, beneath the Somalian lithosphere, the surfacewave model shows a coherent north-south trend. The surface waves average horizontal structure over a few hundred kilometres in length scales. Within the Ethiopian Rift valley, the anisotropy appears weak, presumably because the surfacewaves average a range of azimuthally anisotropic structures. Beneath Tanzania, the fast shear-wave direction is oriented roughly east-west and parallels the palaeo-fabric of the Tanzanian craton (e.g. Shackleton 1986).

At greater depths, beneath the EARS lithosphere, the anisotropy shows a consistent NE orientation, which parallels the rift from Tanzania to Arabia. This is roughly the orientation of the inferred large deep-seated African superplume as it rises towards Arabia (Ritsema \& Allen 2003).

\section{SKS splitting along the EAR}

SKS splitting analysis has been performed in many regions of continental rifting. In general, the orientation of the fast shear-wave is usually rift parallel, but there are some interesting variations. Fast shearwave polarizations beneath the Rio Grande Rift are consistently rift parallel (Sandvol et al. 1992; Gök et al. 2003), whereas within the Baikal Rift the fast polarization directions are perpendicular to the rift (Gao et al. 1994). Gao et al. (1997) argue that fossil fabric beneath a rift should be weakened due to the enhanced mobility of olivine crystals at higher temperatures. However, recent studies of lithospheric peridotities affected by plumes do not seem to show this effect (Vauchez \& Garrido 2001; Vauchez et al. 2005). Gao et al. (1997) also note that tomography results suggest that mantle beneath the Baikal Rift is cooler than beneath the Rio Grande Rift or EARS. Where temperatures are high enough to produce melt, rift-related anisotropy may be due to OMP (Kendall 1994: Gao et al. 1997).

There have been a number of studies of SKS splitting along the EARS (see compilation in Fig. 4). SKS splitting at permanent stations in Africa exhibit little variation in splitting parameters with source backazimuth, and it is therefore argued that the upper-mantle anisotropy is due to a simple single layer (Ayele et al. 2004: Barruol \& Ben Ismail 2001; Walker et al. 2003). Aycle et al. (2004) interpret splitting in Kenya, Ethiopia and Djibouti in terms of melt, noting that the magnitude of the splitting correlates with amount of melt production.

In Tanzania and Kenya, data from temporary seismic deployments show fast shear-wave 
(a) $075 \mathrm{~km}, 8 \mathrm{~Sv}$ \% wrt $\mathrm{km} / \mathrm{s}$

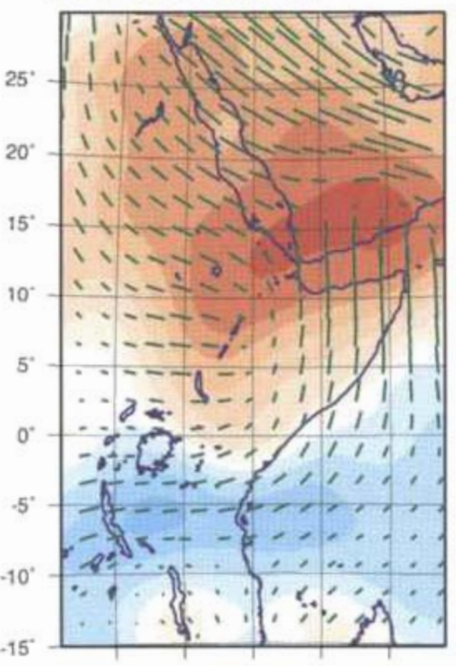

घ)

(d) $1.50 \mathrm{~km}, 6 \mathrm{~Sv} \%$ wrt $4.416 \mathrm{~km} / \mathrm{s}$

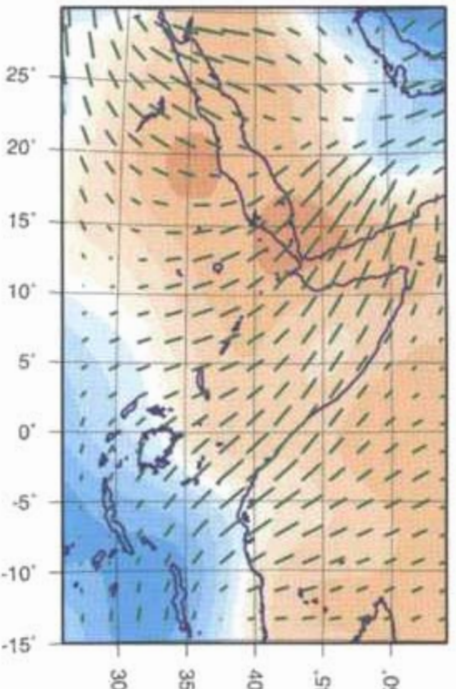

\& ज ثै if (b) $100 \mathrm{~km}, 8 \mathrm{~Sv} \%$ wrt $4.412 \mathrm{~km} / \mathrm{s}$

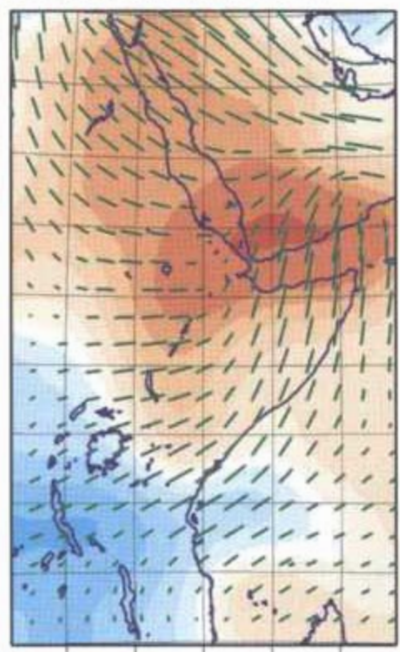

\&ु \& oे in के

(c) $200 \mathrm{~km}, 85 \mathrm{~s}$ \% wr $4.480 \mathrm{~km} / \mathrm{s}$

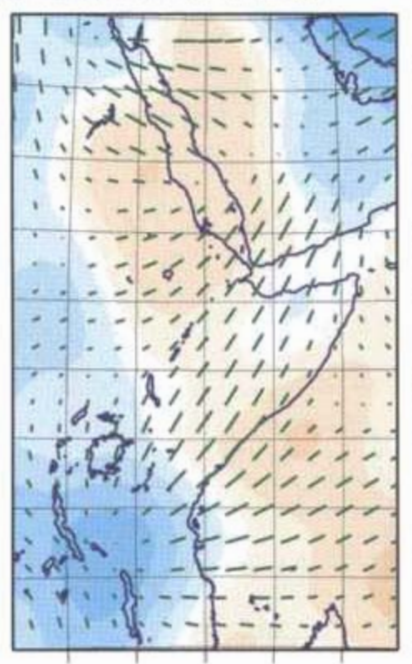

\& $\Leftrightarrow$ ô in iे (c) $125 \mathrm{~km}, \delta \mathrm{Sv}$ \% wrt $4.413 \mathrm{~km} / \mathrm{s}$

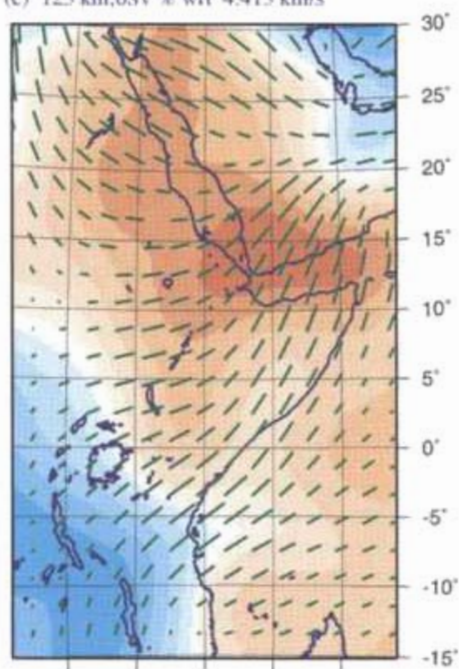

ष् ६ के iे i

(f) $250 \mathrm{~km}, \widehat{\delta S v} \%$ wri $4.632 \mathrm{~km} / \mathrm{s}$

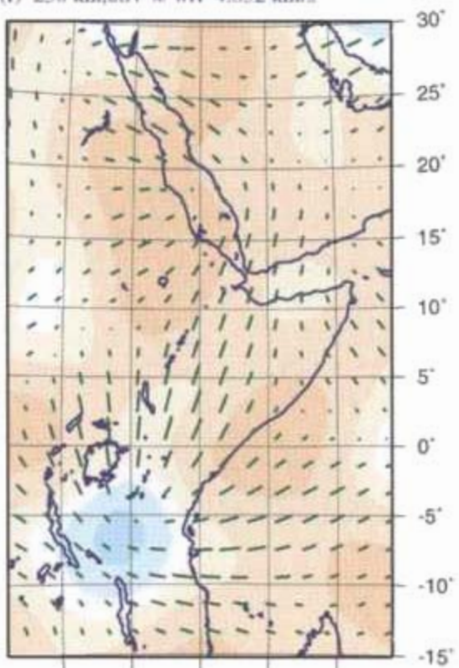

\& $\%$ of is :

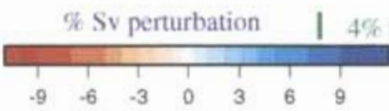

Fig. 3. Tomographic model of the regional. multimode surface-wave tomography study of Debayle $e t$ al. (2005). Maps show horizontal sections through the 3D model at depths of (a) $75 \mathrm{~km}$; (b) $100 \mathrm{~km}$; (c) $125 \mathrm{~km}$; (d) $150 \mathrm{~km}$ : (e) $200 \mathrm{~km}$; (f) $250 \mathrm{~km}$. The background colours show $\mathrm{Sv}$ heterogeneity with respect to the starting background model (PREM); red and blue colours indicate areas of slower and faster wave propagation with respect to PRF:M and the reference velocity is shown at the top of each map. Green bars indicate fast directions for horizontally propagating $\mathrm{Sv}$-waves and their length is proportional to the magnitude of the azimuthal anisotropy.

polarizations parallel to the edges of the castern and western arms of the EARS that encircle the Tanzanian craton (Gao et al. 1997: Walker et al. 2003). Gao et al. (1997) interpreted rift-parallel anisotropy in terms of an OMP mechanism. The magnitude of splitting is much smaller in the south where the rift is youngest. Measurements away from the rift, from the craton and the SE part 

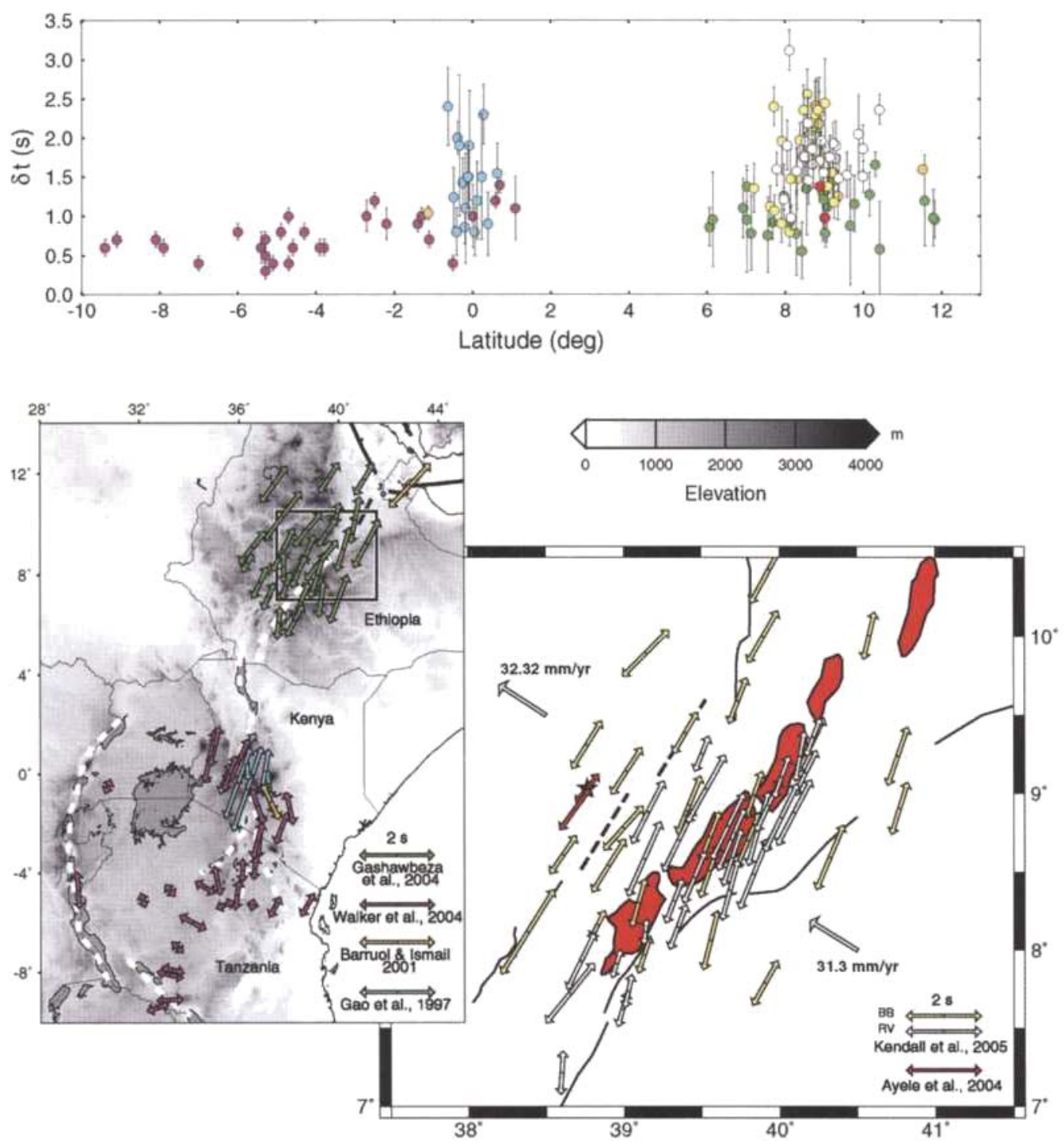

Fig. 4. SKS splitting measurements along the EARS; dashed white line on regional map (lower left) shows outline of rift. Lower right shows detail from Northern Ethiopian Rift. Major mid-Miocene border faults and monoclines are marked with solid and dashed lines, respectively. Larger grey arrows show direction of absolute plate motion.

Quaternary magmatic segments are shaded in red. In both maps, arrows show orientation of fast shear-wave and length of arrow is proportional to magnitude of splitting. Magenta arrows show results of Walker et al. (2004); blue show results of Gao et al. (1997); green, Gashawbeza et al. (2004); orange, Barruol \& Ben Ismail (2004); red, Ayele et al. (2004); yellow and white show results from NMER (see Kendall et al. 2005). Top figure shows SKS splitting (dt) as a function of latitude. Circle colours match those used for the maps.

of the rift extending into the Mozambique Belt, are somewhat different (Walker et al. 2003). Splitting beneath the Tanzanian craton is much weaker and oriented in a more east-west direction, in alignment with Precambrian structural trends (Shackleton 1986). Walker et al. (2003) interpret the splitting pattern in terms of a number of mechanisms including: asthenospheric flow around a cratonic keel, plume-lithosphere interactions, preexisting lithospheric fabric and melt-induced anisotropy. Anisotropy due to asthenospheric flow around continental keels has been used to explain 
patterns of SKS splitting around cratonic North America (Fouch et al. 2000). SKS splitting due to plume-lithosphere interactions beneath Tanzania have been predicted by Sleep et al. (2002), but it is difficult to constrain such interpretations as the location or even present-day existence of the plume is unknown. Weeraratne et al. (2003) use Rayleigh-wave tomography to infer the location of a plume beneath the Tanzanian craton, but the predicted SKS splitting is inconsistent with the observations (Walker et al. 2003).

More recently, Kendall et al. (2005) made over 500 SKS splitting measurements at over 70 J:AGLE temporary stations centred on the NMER (Fig. 4). The orientation of the fast shear-waves are roughly rift parallel. The magnitude of the splitting varies considerably over short distances $(<40 \mathrm{~km})$ and arguments based on the size of liesnel zone (Rümpker \& Ryberg, 2000) constrain the differences in anisotropy to the uppermost $100 \mathrm{~km}$. There will also be a weaker, but more uniform, contribution to the SKS splitting from the underlying large-scalc flow in the region, as revealed by surface waves. In general, the degree of splitting increases northward towards the more oceanic part of the rift, but is highest near the flanks of the rift. On the flanks of the rift the orientation of the fast shear-waves parallel the border faults and monoclines. Within the rift valley the orientation of the anisotropy rotates counterclockwise and follows the en-echelon orientation of the magmatic segments. The shallow source of anisotropy, increased splitting in more magmatic regions, and the anisotropy alignment with magmatic segments lead to the interpretation that the anisotropy is controlled by OMP.

In contrast, Gashawbeza et al. (2004) measure SKS splitting with a wider-aperture network, bul again the fast shear-wave polarizations are parallel 10 the trend of the rift. They argue that the anisotropy beneath Ethiopia is Precambrian in origin with some Neogene reworking near the rift. They draw on interpreted suture orientations inferred from ophiolite belts (Berhe 1990), but as noted previously these interpretations are somewhat controversial (Church et al. 1991) (sec also discussion).

In summary, observations of SKS splitting within EARS rift valleys are conformal to the trend of the rifts. Based on observations of SKS splitting alone, it is difficult to discriminate between anisotropy due to olivine LPO associated with asthenospheric flow, fossil anisotropy in the lithosphere surrounding the rift, and anisotropy due to OMP. However, the fast shear-wave orientations are clearly not aligned with directions of absolute plate motion (APM), thus ruling out anisotropy due to simple asthenospheric flow coupled to the base of the plates. The observations are also not in agreement with predictions of extension-induced olivine LPO (e.g. Blackman et al. 1996; Vauchez et al. 2000), as observed at the East Pacific Rise (Wolfe \& Solomon 1998) and in the perhaps cooler Baikal Rift (Gao et al. 1997), where fast shear-wave polarizations are perpendicular to the spreading direction.

\section{Surface-wave anisotropy within the Northern Ethiopian Rift}

A more-detailed picture of anisotropy beneath the Ethiopian Rift valley is obtained from the analysis of Rayleigh-Love wave propagation within the rift valley. Pilidou et al. (2004) analysed nearly 80 Rayleigh- and Love-wave scismograms from 23 local. regional and teleseismic events, recorded at 20 EAGLE broadband stations. Group velocities are measured from local rift earthquakes with propagation paths of length $400-800 \mathrm{~km}$. Phase velocities are measured along interstation propagation paths of length $30-250 \mathrm{~km}$. With both, the paths cross the rilt valley with a wide range of azimuths. Such analyses allow us to test the LPO and OMP hypotheses. The predicted magnitude of Love-Rayleigh-wave model discrepancies can be similar for LPO and OMP mechanisms, but azimuthal variations predicted by these models are quite different (sce Fig. 2).

Pilidou et al. (2004) follow a two-step procedure to determine path-averaged Earth models. In the first step, they calculate the group/phase velocity dispersion for the fundamental mode along a given path, and higher modes where the data allow it. In the second step, they match, through inversion, each dispersion curve with a theoretical dispersion curve for a suitably chosen layeredEarth model. The Rayleigh- and Love-waves are inverted separately. Data in the period range of 5-50 sec are analysed, which resolves Earth structure in the uppermost $75 \mathrm{~km}$. Horizontal resolution at a depth of $50 \mathrm{~km}$ is roughly $50 \mathrm{~km}$ for the $\mathrm{Sv}$-waves and $80 \mathrm{~km}$ for Sh-waves. Figure $5 \mathrm{sum}$ marizes the results.

In the upper $10 \mathrm{~km}$, Sh-waves are faster than $S v$ waves, independent of azimuth. Surface-wave anisotropy in the shallow crust beneath the NMER is therefore best explained with a VTI model, most probably caused by the layering of volcanics and sediments in the uppermost crust (e.g. see Mackenzie et al. 2005; Keller et al. 2003).

Beneath $20 \mathrm{~km}$, there is a clear azimuthal variation in the shear-wave velocities. For wave propagation along the axis of the rift valley, the Sv model consistently shows faster velocities than the Sh model. At more oblique angles to the rift axis, the anisotropy is diminished and the $\mathrm{Sh}$ velocities 

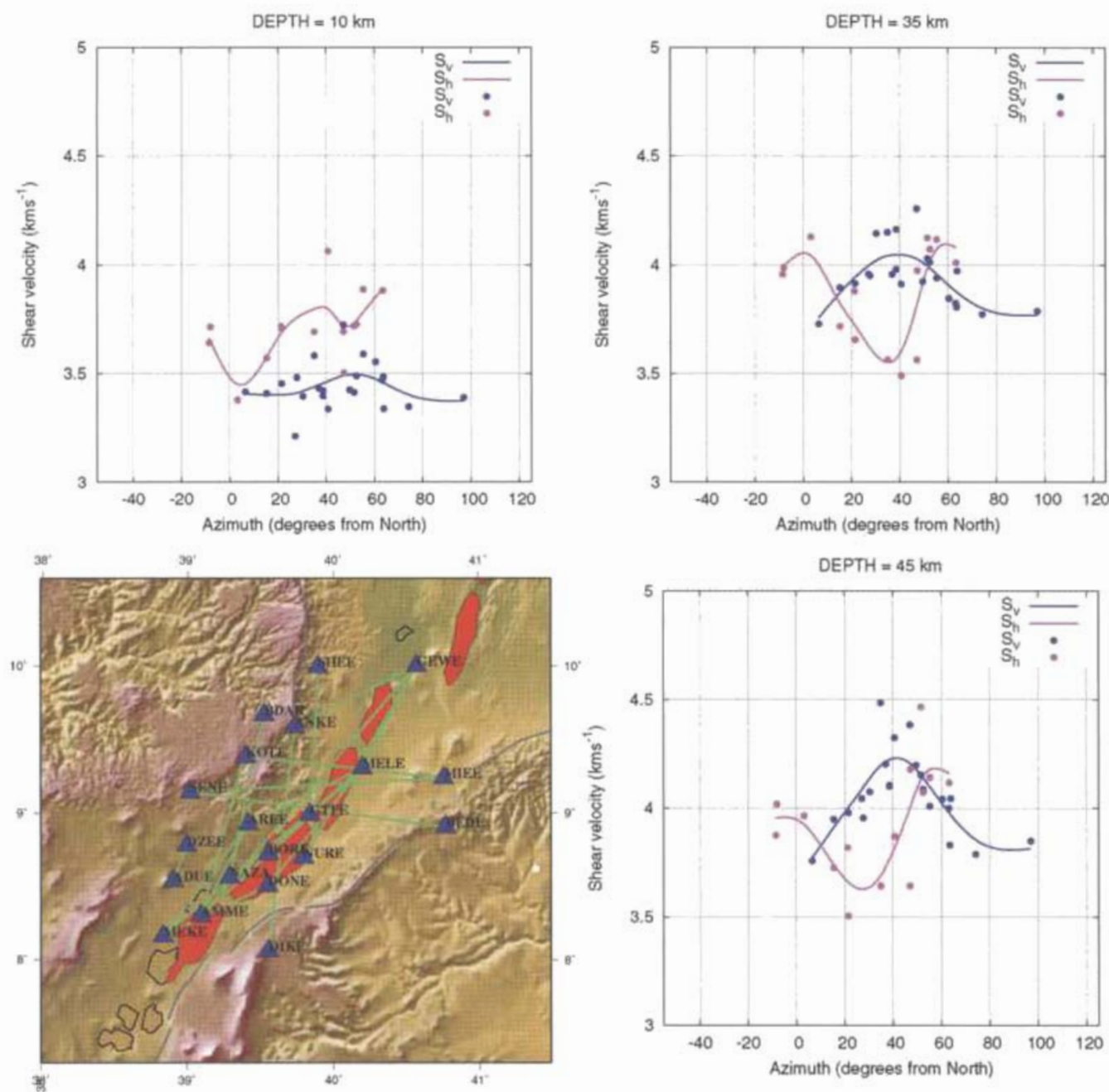

Fig. 5. Surface-wave anisotropy within the NMER. Azimuthal variation in Sv (blue) and Sh (pink) wavespeeds at depths of $10 \mathrm{~km} .35 \mathrm{~km}$ and $45 \mathrm{~km}$. Solid line is natural smooth spline fit to individual measurements and azimuth is measured clockwise from north. Estimates are made from group velocity measurements made on local events and interstation phase velocity measurements (see Pilidou et al. (2005) for more detail). Map shows the interstation paths for phase velocity measurements.

become faster than the Sv velocities. This pattern is similar to that predicted with the OMP model where the normal to the melt pockets is perpendicular to the rift axis (Fig. 2). This is in contrast to the velocities predicted from the peridotite anisotropy, which predict very little anisotropy for the limited range of directions where $S v$ velocitics are faster than $\mathrm{Sh}$ velocities. These models therefore suggest OMP as the primary mechanism for anisotropy beneath the rift to the maximum depth of resolution $(\sim 70 \mathrm{~km})$. The OMP anisotropy is over $12 \%$ and extends over at least $50 \mathrm{~km}$ of the upper mantle.
This would produce over 1.5 seconds of SKS splitting, which is roughly the average amount of SKS splitting observed in the NMER valley (Kendall et al. 2005).

\section{Shear-wave splitting in crustal earthquakes}

Shear-wave splitting in shallow earthquakes can be used to study the anisotropy within the crust if events lie within a near-vertical cone beneath the 
station (the so-called shear-wave window of Booth \& Crampin 1985). Keir et al. (2005) analysed events at depths between 6 and $25 \mathrm{~km}$ beneath the EAGLE stations. The orientations of fast shearwaves at these stations parallel local surface features (Fig. 6). For example, the splitting at ANKE parallels the nearby mid-Miocene Ankober border fault. Within the rift valley, the anisotropy generally parallels Quaternary-age eruptive centres and active faults.

A VTI crust due to fine-scale layering, as suggested for the rift valley by the surface-wave analysis, will not generate any splitting in nearvertically propagating shear waves. Therefore, the anisotropy is most likely due to vertical cracks or inclusions aligned by regional and local stresses in the crust. The magnitude of the splitting varies dramatically across the EAGLE network, suggesting a heterogeneous stress field or variations in the underlying cause of anisotropy. The deepest events lie beneath the Ethiopia plateau and although they show small splitting values (up to $0.15 \mathrm{sec}$ ), they show clear depth-dependent variations in shearwave splitting to a depth of $25 \mathrm{~km}$. This suggests roughly $1 \%$ anisotropy beneath the plateau. In contrast, earthquakes $7 \mathrm{~km}$ bencath the Boset magmatic segment show $0.24 \mathrm{sec}$ of splitting. which translates to over $6 \%$ anisotropy. Stations within the rift valley but located outside magmatic segments show less splitting (e.g. MELE or E79), but the average magnitude of splitting in the rift valley is nearly $3 \%$, much larger than that beneath the plateau to the NW.

Where it is possible to compare, the orientation of the fast shear-wave agrees with the direction of maximum horizontal stress, as inferred from focal

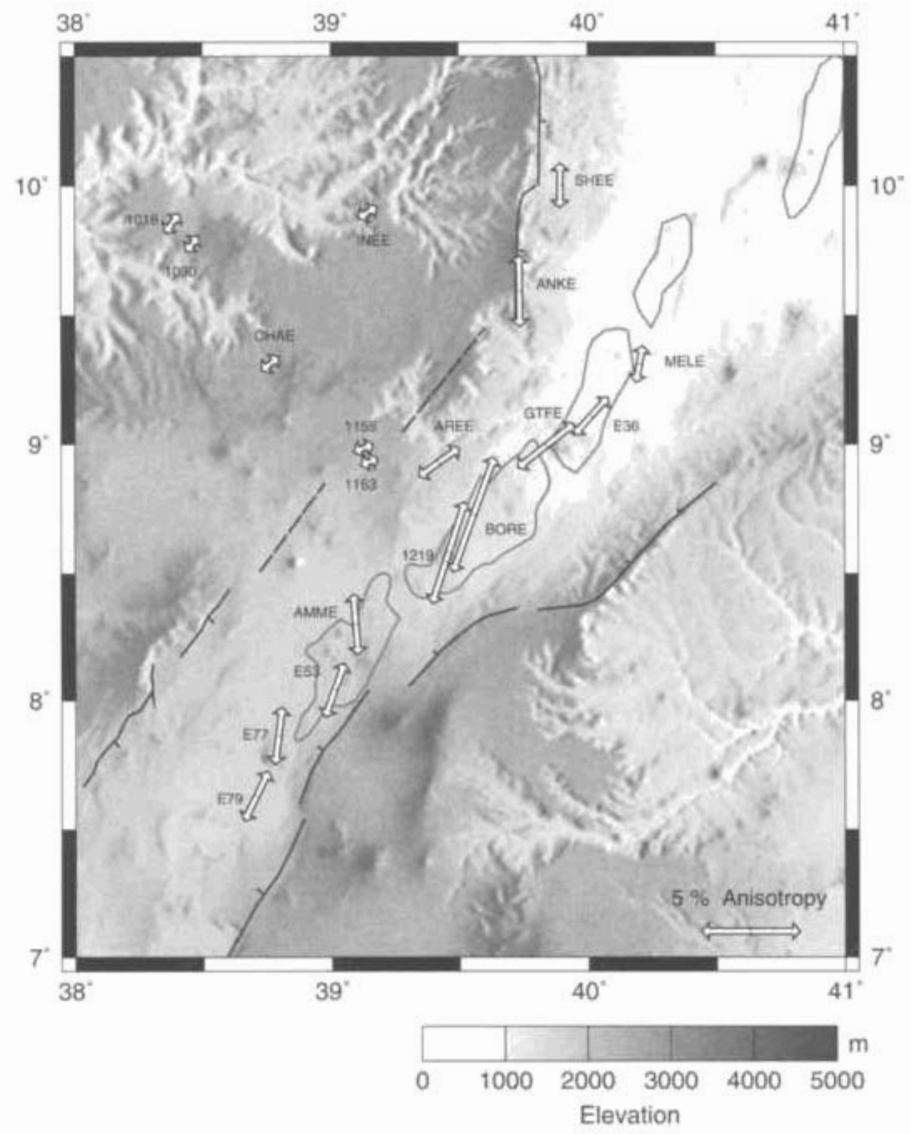

Fig. 6. Crustal anisotropy as determined from shear-wave splitting in crustal earthquakes. Calculation assumes anisotropy is uniformly distributed between the source and receiver. Orientation of arrows shows polarization of fast shear-wave, whilst the length of the arrow is proportional to the magnitude of the anisotropy. Heavy black lines show orientation of border faults, dashed lines show monoclines and thin lines show outline of magmatic segments in the rift valley. 
mechanisms (Keir et al. 2006). Keir et al. (2005) interpret these observations in terms of the injection of vertically aligned magma intrusions or cracks beneath the Quaternary magmatic segments. Stations outside the rift show directions sub-parallel to metamorphic basement fabrics, consistent with melt decrease away from the rift. Support for this interpretation comes from other geophysical studies. Keranen et al. (2004) and Tiberi ef al. (2005) interpret cooled mafic intrusions in the middle to lower crust beneath these magmatic segments using wide-angle refraction tomography and gravity models, respectively. The anomaly under Boset is especially pronounced, where meltrelated anomalies have been interpreted in magnetotelluric (MT) (Whaler \& Hautot 2006) and gravity (Comwell et al. 2006) data. There is evidence for melt in the lower crust beneath the Ethiopian plateau, both in the past and at present, from wide-angle seismic refraction images of underplating (MacKenzie et al. 2005), mid-crustal conductive anomalies in MT data (Whaler \& Hautor 2006), and Quaternary eruptive centres as far north as I Lake Tana. Cumulativcly, these results suggest the anisotropy is related to variable amounts of melt pocket alignment in the crust, with a higher degree of dyke intrusion in the crust beneath the rift.

\section{Synthesis of results}

\section{Large-scale flow}

Deep mantle flow associated with the African superswell is oriented in a rift-parallel direction beneath the EARS. The signature of this is perhaps evident in the pattern of surface-wave anisotropy at depths below $125 \mathrm{~km}$ (Debayle et al. 2005). It has been argued that this large-scale flow pattern is responsible for the dynamic topography of Africa (Lithgow-Bertelioni and Silver 1998; Gurmis et al. 2000) and Arabia (Daradich et al. 2003 ) and the EARS plate motions (Calais et al. 2006). The interaction of this density-driven flow with absolute plate motions has also been used to explain SKS splitting observations at permanent stations on islands surrounding Africa (Behn et al. 2004). In fact, the regional patterns of surfacewave anisotropy (Fig. 3) are reminiscent of the flow patterns predicted by Behn et al. (2004). It is therefore plausible that the sub-lithospheric anisotropy beneath the EARS is due to olivine LPO caused by viscous coupling between the overlying plates and a superplume that rises beneath Tanzania (e.g. Sleep et al. 2002).

The precise architecture of the upwelling uppermantle beneath Africa is uncertain. The number of proposed plumes beneath Africa ranges from as few as one to as many as 40 (Davies 1998). Furthermore, based on laboratory experiments, the stability of a single large inclined superplume has been questioned (Davaille et al. 2005). Hence the pattern of sub-lithospheric anisotropy may be related to a more complicated pattern of upwellings from the deep mantle beneath Africa. Instead of a large single superplume beneath the upper mantle, there may be more than one plume head beneath our study region. For example, recent tomographic images suggest a plume beneath the Red Sea/Gulf of Aden that extends vertically into the lower mantle (Montelli et al. 2004). Future regionalscale seismic experiments will help address this issue by better delineating mantle structure beneath Africa (e.g- AfricaArray http://africaarray. psu.edu; Dalton 2005).

Anisotropy beneath Africa cannot be explained by the direction of absolute plate motion. Africa is nearly stationary in a holspot reference frame and the Nubian and Somalian plates move slowly in a northwesterly direction (Fig. 4). However, recent analysis of GPS and earthquake slip vector data (Calais et al. 2006) show relative extension directions across the rift valleys, which are consistently perpendicular to the polarization of the fast shear-wave.

\section{Magma assisted rifting}

It is difficult to reconcile the rift valley surface-wave anisotropy and SKS splitting directions with a model of olivine alignment beneath the Ethiopian rift. This precludes olivine alignment due to current processes (either mechanical extension or flow along the rift axis) or fossil fabric within pre-existing lithosphere. Instead, melt pockets oriented in a rift-parallel direction explain the observations remarkably well (sec Fig. 2). The combined body-wave and surface wave results provide robust evidence for aligned melt beneath the Northern Ethiopian Rift to depths of at least $75 \mathrm{~km}$. This is further supported by structural (Ebinger \& Casey 2001; Wolfenden et al. 2004), geochemical (Rooney et al. 2005), earthquake seismicity (Keir et al. 2006) and controlled-source seismic (Keranen et al. 2004) data, which indicate that the magmatic segments are zones of intense dyke injection and magmatic intrusion. Major element analyses of xenoliths from the Bishoftu area (near station DZEE, Fig. 1) suggest melting at depths up to $75 \mathrm{~km}$ (Rooney et al. 2005).

Regional tomography (Green et al. 1991; Ritsema et al. 1998; Bastow et al. 2005) show highly focused low-velocity anomalies beneath continental parts of the EARS. Vp/Vs ratios suggest that these anomalies may indicate partially molten mantle (Bastow et al. 2005). Anisotropy due to OMP explains how 
remarkably conformal the SKS splitting polarizations are to the rift valleys. This is further supported by the fact that the magnitude of the splitting (dt) increases moving northward in the direction of increased magma production (Fig. 4).

Shear-wave splitting in crustal earthquakes suggests that the melt-induced anisotropy persists well into the crust. There is an apparent contradiction between the rift-valley surfacc-wave results and the crustal splitting. This is resolved with a model of layered sediments and volcanics, punctuated by vertically aligned dykes and intrusions. The resulting anisotropy will be orthorhombic in symmetry. Vertically propagating shear-waves will not be sensitive to VTI anisotropy caused by the layering. In contrast, the surface-waves, with poorer lateral resolution, will not be able to resolve the localized and highly variable anisotropy beneath the magmatic segments and thus be most sensitive to the layering.

Although the anisotropy beneath the rifts appears to be dominated by melt, it is likely to be due to a range of mechanisms. Holtzman et al. (2003a) show strain partitioning and melt segregation in laboratory simulations of dunite deformation. These experiments suggest that anisotropy in deformed regions of partial melt may be due to OMP, LPO and the periodic layering of melt-rich and melt-poor bands. Interestingly, these experiments show olivine a-axis [100] alignment in the shear plane, but orthogonal to the shear direction. For vertical flow, the olivine $a$-axis alignment will be horizontal and riftparallel, further accentuating the anisotropy due to aligned melt pockets and melt bands. Cumulatively, these mechanisms are highly effective in generating seismic anisotropy (Holtzman et al. 2003b).

Evidence of melt-related anisotropy is important as it supports ideas of magma-assisted rifting. An asthenospheric upwelling will heat the lithosphere and produce melt, thus reducing the strength of the lithosphere enough for it to rupture without large amounts of stretching (Buck 2004). Strain gradients will focus and align the melt in the mantle beneath rift shoulders, as predicted by Sleep (1997) and observed by Kendall et al. (2005). Melt is then focused up to the rift axis, eventually erupting at magmatic segments and perhaps following strain gradients (e.g. Phipps-Morgan 1987).

Regional tomography and geochemical studies indicate localized upwellings or small plumes that may originate from the African superplume. These will thermally thin the lithosphere and lead to decompression melting and magma injection into the lithosphere. The distant forces acting on the African plates are weak, but the extra forces due to small-scale convection beneath the rift may be sufficient to rift the weakencd lithosphere (Burov \& Guillou-Frottier 2005).

\section{Pan-African fabric}

There is likely to be fossil anisotropy within the ancient lithosphere away from the rift valley. SKS splitting beneath the Tanzanian craton is weak, but parallels Precambrian Pan-African fabric (Walker et al. 2004). In general, cratonic fabric in Africa appears to generate small amounts of SKS splitting (e.g. Kaapvaal (Silver et al. 2001; Fouch et al. 2004); Congo (Ayele et al. 2004)).

The pre-existing lithospheric fabric in Ethiopia is less clear, owing to the cover of pervasive flood basalts. Mesozoic rift structures strike NW-SE, and Pan-African structural trends are oriented north-south (e.g. Moore \& Davidson 1978). However, based on the orientation of ophiolite belts, Berhe (1990) inferred a NE-SW trending suture that connects the north-south Turkana trending suture and the north-south trending Nabitah suture in Arabia. In contrast, Stern et al. (1990) have used the same ophiolite belts to suggest a major east-west suture in this region that is in part marked by chains of eruptive volcanic centres (e.g. the Ambo lineament). Due to limited basement outcrop, the interpretation of such sutures is controversial (Church 1991). SKS splitting beneath the Ethiopian plateau roughly aligns (within 20-30 degrees) with the suture oricntation proposed by Berhe (1991) (Gashawbeza 2004). Vauchez et al. (1997) have argued that there is correlation between mechanical anisotropy and pre-existing anisotropic fabric; in other words, rifting has a tendency to occur along previous sutures. In contrast, larger-scale surface-wave anisotropy shows a northwest orientation in the upper $75 \mathrm{~km}$ beneath the Ethiopian plateau and a north-south orientation in the deeper lithosphere. These surface waves will average structures over large horizontal distances and will see the cumulative effect of any preexisting fabric and/or aligned melt. Any fossil anisotropy will be more dominant away from the rift valley. It would appear that the surface waves are not capable of resolving the near-surface near-rift melt-related anisotropy.

Beneath the Ethiopian plateau (NW of the rift), the fast shear-wave orientations remain rift-parallel over $200 \mathrm{~km}$ from the rift flanks (Gashawbeza $e t$ al. 2004; Kendall et al. 2005; Keir et al. 2005). As discussed, this may indicate pre-existing structural trends, but the signal may be still due to aligned melt in the lower crust and uppermost mantle, as it is beneath the rift valley. Indeed, there is further evidence for magmatism under the plateau. Whaler \& Hautot (2006) see evidence from magneto-telluric surveying for large conductive bodies in the mid-crust. MacKenzie et al. (2005) interpret crustal underplating beneath this region in a wide-angle reflection profile (see also 


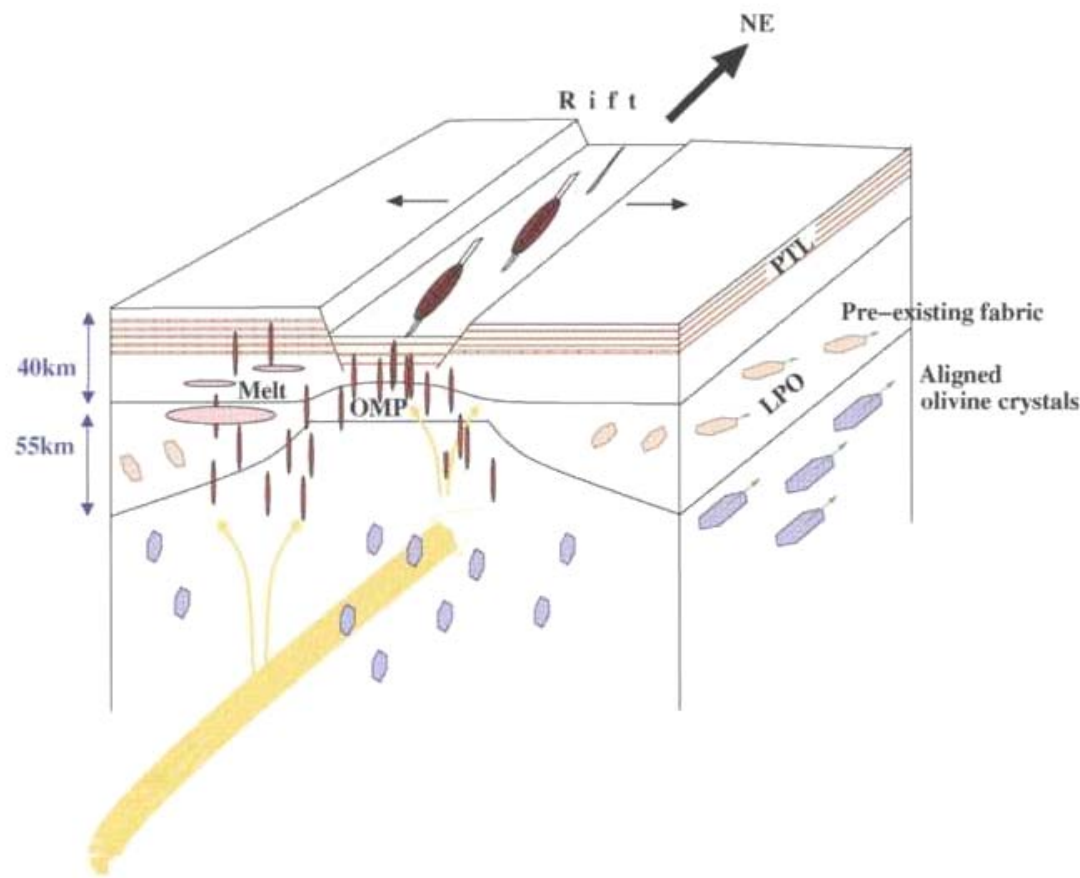

Fig. 7. Model of seismic anisotropy beneath the EARS. A range of mechanisms is responsible for anisotropy, including periodic thin layering (PTL) of contrasting materials, oriented pockets of melt (OMP), and the latticepreferred orientation (LPO) of olivine crystals. OMP anisotropy is most effective if the anisotropy is aligned in thin disk-like pockets. Away from the rift, the lithospheric LPO is due to pre-existing fabric, whilst beneath the lithosphere the LPO is due to viscous coupling between the base of the lithosphere and large-scale mantle upwelling.

Maguire et al. 2006). Evidence from surface geology and magneto-telluric data of Quaternary volcanism and dyking is observed as far north as Lake Tana (Hautot et al. 2006). Finally, fine-scale tomographic images show a large low-velocity velocity anomaly beneath the Ethiopian plateau, offset northwestward from the rift valley. Analysis of $\mathrm{Vp} /$ $\mathrm{V}$ s ratios derived from $\mathrm{P}$-wave and $\mathrm{S}$-wave models suggests this anomaly is most probably melt related and not purely thermal in origin (Bastow et al. 2005). Therefore, beneath the Ethiopian plateau the anisotropy may be due to a complicated combination of mechanisms associated with pre-existing fabric, fault trends and aligned melt. This may explain discrepancies in the surface-wave and body-wave results, as they are sensitive to different lateral and vertical length scales.

\section{Summary}

Figure 7 summarizes our working model of anisotropy beneath the EARS. Shear tractions and buoyancy forces induced by deep mantle flow appear to drive rifting in Africa. In this model, the large-scale
African superplume feeds smaller plumes or upwellings that impinge on the base of a heterogeneous lithosphere (e.g. Ebinger \& Sleep 1998). The plume material flows around rigid keeled cratonic blocks, pooling beneath lithospheric thin spots (Sleep et al. 2002), which correlate with preexisting rift zones and/or sutures (Dunbar \& Sawyer 1989; Vauchez et al. 1997; Ebinger \& Sleep 1998). The strain associated with rifting is then accommodated by magma injection along narrow plate boundaries, not diffuse regions. Extension is accommodated in focused zones of melt production where magma injection outpaces faulting. Anisotropy in the rift valley is dominated by the melt signature, whilst the pre-existing Pan-African anisotropic fabric contributes a weak signature away from the rift. The wide range of observations of seismic anisotropy beneath Africa hold a signature of the processes that lead to rifting and eventual formation of an ocean basin.

Cindy Ebinger is thanked for fruitful discussions and guidance. This work would not have been possible without cooperation and collaboration between members of the EAGLE working group (Maguire et al. 2003). Peter 
Maguirc, James Wookey, Kathy Whaler and Dave Cornwell are thanked for helpful comments. The manuscript was improved by insightful reviews from Andy Nyblade and two anonymous reviewers. Eric Debayle is thanked for making available his surface wave velocity model. SEIS-UK is acknowledged for equipment and technical support. This work was supported by NERC grant NER/ A $/ \mathrm{S} / 2000 / 01003$

\section{References}

Abdelsel.am. M. \& Stern, R. 1996. Sutures and shear zones in the Arabia-Nubian shield. Journal of African Earth Sciences, 23, 289-310.

Ayele, A., StuART, G.W. \& Kendall., J.-M. 2004. Insights into rifting from shear-wave splitting and receiver functions: an example from Ethiopia. Geophysical Joumal International, 157, 354362.

BACKUS, G. 1962. Long-wave elastic anisotropy produced by horizontal layering. Journal of Geophysical Research, 67, 4427-4440.

BarruOL, G. \& BEN-ISMAIL, W. 2001. Upper mantle anisotropy beneath the African IRIS and GEOSCOPE stations. Geophysical Joumal International, 146, 549-561.

Bastow, I.D., Stunt, G.W., Kendall, J.M. \& EBINGl:R, C.J. 2005. Upper mantle seismic structure in a region of incipient continental breakup: northern Ethiopian rift. Geophysical Journal International, 162, 479-493.

Behn, M.D., Conrad, C.P. \& Sil.ver, P.G. 2004 Detection of upper mantle flow associated with the African superplume. Earth and Planetary Science Letters, 224, 259-274.

Ben Ismaïl, W. \& Mainprice, D. 1998. An olivine petrofabric database: An overview of upper mantle fabrics and seismic anisotropy. Tectonophysics, 296, 145-157.

Benolt, M. Nyblade, A.A. Vandecar, J.C. \& GURROLA. H. 2003. Upper mantle P-wave velocity structure and transition zone thickness beneath the Arabian shield. Geophysical Research Letters, 30. 1531, doi 10.1029/2002GLO16436.

BenoIT, M., Nybi.aide, A.A. \& VandeCar, J.C. 2006. Upper mantle P-wave speed variations beneath Ethiopia and the origin of the Afar Hotspot. Geology (in press).

Berhe, S.M. 1990. Ophiolites in Northeast and East Africa: Implications for Proterozoic crustal growth. Journal of the Geological Society, Londor, 147, 4I-57.

Bilham, R., Bendick, R., Lakson, K., Mohr, P., Braun, J., Tesfaye, S. \& Asfaw, L. 1999. Secular and tidal strain across the Main Ethiopian Rift. Geophysics Research Letters, 26, 2789-2792.

Bl.aCKMAN, D. \& Kendall, J.-M. 1997. Sensitivity of teleseismic body waves to mineral texture and melt in the mantle beneath a mid-ocean ridge. Philosophical Transactions of the Royal Society of London, 355, 217-231.

Blackman, D.K. \& Kendali., J.-M. 2002. Seismic anisotropy of the upper mantle: 2 . Predictions for current plate boundary flow models. Geochemistry,
Geophysics, Geosystems, 3, 8602, doi:10.1029/ $2001 \mathrm{GC} 000247$

Bl.ACKMan, D.K., KeniJall, J-M., Dawson, P. Wenk, H-R., Boyce, D. \& Phipps Morgan, J. 1996. Teleseismic imaging of subaxial flow at mid-ocean ridges: travel-time effects of anisotropic mineral texture in the mantle. Geophysical Journal International, 127, 415-426.

Boccaletti, M., Bonini, M. Mazzuoli. R., Abebe, B., Piccardi, L. \& Tortorici, L. 1998. Quaternary oblique extensional tectonics in the Ethiopian Rifi (Horn of Africa). Tectonophysics, 287, 97-116.

Booth, D.C. \& Crampin, S. 1985. Shear-wave polarizations on a curved wavefront at an isotropic free-surface. Geophysical Journal of the Royal Astronomical Society, 83, 31-45.

Buck, W.R. 2004. Consequences of asthenospheric variability on continental rifting, In: KARNER, G.D. TAYLOR, B.N. DROSCOLI., W. \& KOHLSTEDT, D.L. (eds) Rheology and Deformation of the Lithosphere at Continental Margins. pp. 1-30. Columbia University Press, New York.

Burov, E. \& Gujllou-Frottier, L. 2005. The plume head-continental lithosphere interaction using a tectonically realistic formulation of the lithosphere. Geophvsical Joumal International, 161, 469-490.

Calais, E., Ebinger, C., Hartnady, C., Nocquet, J.M. 2006. Kinematics of the East African Rift from GPS and earthquake slip vector data. In: Yirgu, G., Ebinger, C., Maguire, P.K.H. (eds) The Afar Volcanic Province within the East African Rift System. Geological Society, London, Special Publications, 259, 9-22.

Church, W.R., Berhe, S.M., Abdei.sal.am, M.G. \& StERN, R.J. 1991. Discussion of ophiolites in Northesast and East Africa: Implications for Proterozoic crustal growth. Journal of the Geological Society, London, 148, 600-606.

Cornwell, D., Mackenzie, G.D., Maguire, P.K.H., ENGLAND, R.W., ASFAW, L.M. \& OI UMA, B 2006. Northern Main Ethiopian Rift crustal structure from new high-precision gravity data. In: YiRgu. G., Ebinger, C. \& MagliRe, P.K.H. (eds) The Afar Volcanic Province within the East African Rift System. Geological Society Special Publications, 259, 307-321.

Courtili.ot, V.C., Manighetti, I., TApponier, P. \& BEssE, J. 1999. On causal links between flood basalts and continental breakup. Earth and Planetary Science Letters, 166. 177-195.

CRAMPIN, S. 1994. The fracture criticality of crustal rocks. Geophysical Journal Intemational, 118, $428-438$.

DaLton, R. 2005. African network set to boost Earth Sciences. Nature, 433, 449.

Daradich, A., Mitrovica, J.X., Pyski,ywec, R.N., WilleE, S.D. \& ForTre, A.M. 2003. Mantle flow, dynamic topography, and rift-flank uplift of Arabia. Geology, 31, $901-904$.

Davaille, A., Stutzmann, E., Sil.veira, G., Besse, J. \& Courtillot, V. 2005. Convective patterns under the Indo-Atlantic. Earth and Planetary Science Letters, 239, 233-252. 
DAviES, G. 1998. A channelled plume under Africa. Nature, 395, 743-744.

Debayle, E., Lévêque, J.-J. \& Cara, M. 2001. Seismic evidence for a deeply rooted low velocity anomaly in the upper mantle beneath the northeastern Afro/Arabian continent. Earth and Planetary Science Letters, 193, 423-436.

Debayle, E., Kfnnett, B.L.N. \& Priestley, K. 2005. Global azimuthal seismic anisotropy and the unique plate-motion deformation of Australia. Nature, 433, 509-512, doi:10.1038/nature03247.

Dunbar, J. \& SAwYER, D. 1989. How pre-existing weaknesses control the style of continental breakup. Iournal of Geophysical Research, 94, $7278-7292$

EBINGER, C.J. 2005. Continental break-up: The East Africa perspective. Astronomy and Geophysics, 46, 2.16-2.21.

Ebinger, C.J. \& SleEp, N.H. 1998. Cenozoic magmatism throughout East Africa resulting from impact of a single plume. Nature, 395, 788-791.

Ebinger, C.J. \& CASEY, M. 2001. Continental brekaup in magmatic provinces: an Ethiopian example. Geology, 29, 527-530.

EVANS, J. \& ACHAUER, U. 1993. Teleseismic tomography using the ACH method: Theory and application to continental scale studies. In: IYER, E. \& Hirahara (eds) Seismic Tomography: Theory and Practice. Chapman and Hall, New York.

Facl, U., TOOMEY, D.R. \& WAFF, H.S. 1994. Intergranular basaltic melt is distributed in thin, elongated inclusions. Geophysical Research Letters, 21, 29-32.

Fouch, M. Fischer, K.M. Parmentier, E.M. Wysession, M.E. \& Clarke, T.J. 2000. Shearwave splitting, continental keels, and patterns of mantle flow. Joumal of Geophysical Resrarch, 105, 6255-6275.

Fouch, M., Sillver, P.G. Bell, D.R. \& LeE, I.N. 2004. Small-scale variations in seismic anisotropy near Kimberley, South Africa. Geophysical Journal International, 157, 764-774, doi: $10.1111 /$ j. $1365-246 \times .2004 .02234 . x$.

Gao, S., Davis, P.M. LiU, H. Slack, P.D. Zorin, Yu, A. Mordvinova, V.V. Kozhevnikov, V.M. \& MEYER, R.P. 1994. Seismic Anisotropy and Mantle Flow beneath the Baikal Rift Zone. Nature, 371, 149-151.

GaO, S., Davis, P.M., ET AL. 1997. SKS splitting beneath continental rift zones. Journal of Geophysical Research, 102, 22781-22797.

Gashawbeza, E.M., Klemperer, S.L., Nyblade, A.A., Walker, K.T. \& Keranen, K.M. 2004. Shear-wave splitting in Ethiopia: Precambrian mantle anisotropy locally modified by Neogene rifting. Geophysical Research Letters, 31, doi:10.1029/2004GL020471

George, R., Rogers, N. \& Kelley, S. 1998. Earliest magmatism in Ethiopia: Evidence for two mantle plumes in one flood basalt province. Geology, 26, 923-926.

Gók., R., NI, J.F., West, M., SAnijvol, E., Wilson, D., Aster, R., BALDRIDGE, W.S., Grand, S., GAO, W., Tillman, F. \& Semken, S. Shear wave splitting and mantle flow beneath LA RISTRA. Geophysics Research Letters, 30(12), 1614, doi:10.1029/ 2002 GL016616.

Green, W.V., Achauer, U. \& Meyer, R.P. 1991. A three dimensional image of the crust and upper mantle beneath the Kenya Rift. Nature. 354, $199-203$.

Gurnis, M., Mitrovica, J.X., Su, W.J. \& Heisst, $H$. van 2000 . Constraining mantle density structure using geological evidence of surface uplift rates: The case of the African plume. Geochemistry, Geophysics, Geosystems, 1, 1999GC000035.

Hadiolche, O., Jobert, N. \& Montagner, J.-P. 1989. Anisotropy of the African Continent inferred from surface waves. Physics of the Earth Planetary Interiors, 58, 61-81.

Hautot, S., Whaler, K., Gebru, W. \& Dessisa, M. 2006. The structure of Mesozoic basin beneath the Lake Tana area, Ethiopia, revealed with magnetotellurics. Journal of African Earth Sciences (in press).

Holtzman, B.K., Kohlstedt, D.L., Zimmerman, M.E., Heidel.bach, F., Hiraga, T. \& Hustoft, J. 2003a. Melt segregation and strain partitioning: Implications for seismic anisotropy and mantle flow. Science, 301, 1227-1230.

Hol_zMan, B.K., KOHLSTEDT, D.L., ZimMERMAN, M.E. \& Kendall, J.-M. 2003b. Melt segregation, strain partitioning, olivine $\mathrm{CPO}$, and the origin of seismic anisotropy in oceanic lithosphere. Eos: Transactions of the American Geophysical Union, 84(46), Fall Meet. Suppl., Abstract T51H-04.

Karato, S. 1992. On the Lehmann discontinuity. Geophysics Research Letters, 19, 2255-2258.

Keir, D., Ebinger, C.J., Kendall, J.-M. \& Stuart, G.W. 2005. Variations in late syn-rift melt alignment inferred from shear-wave splitting in crustal earthquakes beneath the Ethiopian rift. Geophysical Research Letters, 32, L23308, doi: 10.1029/ 2005 GL024150.

Keir, D., Ebinger, C.J., Stuart, G.W., Daly, E. \& AYElE, A. 2006. Strain accomodation by magmatism and faulting as rifting proceeds to breakup: Seismicity of the northern Ethiopian rift. Submitted to Joumal of Geophysical Research (in press).

Keller, G.R., Harder, S.H., O'Rhilly, B., Mickus, K., TAdesse, K., Maguire, P.K.H. \& EAGLE WORKING GROUP 2004. A preliminary analysis of crustal structure variations along the Ethiopian Rift. Proceedings of the International Conference on the East African Rift System, June 20-24 2004, Addis Ababa, Ethiopia, 97-101.

KENDALL, J.-M. 1994. Teleseismic arrivals at a midocean ridge: effects of mantle melt and anisotropy. Geophysical Research Letters, 21, 301-304.

Kendall, J.-M. 2000. Seismic anisotropy in the boundary layers of the mantle. In: Karato, S., Stixrude, L., Liebermann, R.C., Masters, T.G. \& FORTE, A.M. (eds) Earth's Deep Interior: Mineral Physics and Tomography from the Atomic to the Global Scale. Geophysical Monograph Series, 117, American Geophysical Union, $149-175$. 
Kendall, J.-M., Stuart, G.W., Ebinger, C.J., BASTOW. I.D. \& KEIR, D. 2005. Magma assisted rifting in Ethiopia. Nature, 433, 146-148.

Keranen, K., Klemperier, S.L., Gloaguen, R. \& EAGLE WORKJNG GROUP 2004. Three-dimensional seismic imaging of a protoridge axis in the Main Ethiopian Rift. Geology, 32, 949-952.

Kirkwood, S.C. \& Crampin, S. 1981. Surface-wave propagation in an ocean basin with an anisotropic upper mantle: Numerical modelling. Geophysical Joumal of the Royal Astronomical Society, 64, $463-485$.

I.iThGow-Bertelloni, (.. \& Silver, P.G. 1998. Dynamic topography, plate driving forces and the African superswell. Nature, 395, 269-272.

Mackenzie, G.D., Thybo, G.H. \& Maguire, P.K. H. 2005. Crustal velocity structure across the Main Ethiopian Rift: results from 2-dimenional wideangle seismic modelling. Geophysical Joumal Intemational, 162, 994, doi:10.1111/j.1365246X.2005.02710.

Maguire, P.K.H., Ebinger, C.J., ET al. 2003. Geophysical project in Ethiopia studies continental breakup. Eos: Transactions of the American Geophysical Union, 84, 337-343.

Maguire, P.K.H., Keller, C.R., et al. 2006. Crustal structure of the northern Main Ethiopian Rift from the EAGLE controlled source survey; a snapshot of incipient lithospheric break-up. In: YIRGU, G. Ebinger, C. \& Maguire, P.K.H. (eds) The Afar Volcanic Province within the East African Rift System. Geological Society, London, Special Publications, 259, 269-291.

Mainprice, D., Tommasi, A., Couvy, H., Cordier, P. \& FROST, D.J. 2005. Pressure sensitivity of olivine slip systems: Implications for the interpretation of seismic anisotropy of the Earth's upper mantle. Nature, 433, $731-733$.

MCKenziE, D. 1978. Some remarks on the developement of sedimentary basins. Earth and Planetary Science Letters, 40, 25-32, 1978.

Mont aGner, J.-P. 1994. What can seismology tell us about mantle convection? Reviews of Geophysics $32,115-137$.

Montelli, R., Nolet, G., Dahlen, F.A., Masters, G., ENGDAHL, E.R. \& HunG, S.-H. 2004. Finitefrequency tomography reveals a variety of plumes in the mantle. Science, 303, 338-343.

MOORE, H. \& DAvidSON, A. 1978. Rift structure in southem Ethiopia. Tectonophysics, 46, 159-173.

Nicholas, A. \& Christlinsen, N.I. 1987. Formation of anisotropy in upper mantle peridotites - A review. In: Fuchs, K. \& FroldavauX, C. (eds) Composition. Structure and Dynamics of the Lithosphere-Asthenosphere System, Geodynamics Series. 16, 111-123, American Geophysical Union, WASHINGTON, DC.

NYBLADE, A.A. \& RoBinson, S.W. 1994. The African superswell. Geophysical Research Letters, 21, $765-768$.

Nyblade, A., KnOx, R. \& Gurrol.A, H. 2000. Mantle transition zone thickness beneath Afar: Implications for the origin of the Afar hotspot. Geophysical Journal International, 142, 615-619.
Nyblade, A.A., OWens, T.J., Gurrola, H., RitSEMA, J. \& LANGSTON, C.A. 2000 . Scismic evidence for a deep upper mantle thermal anomaly beneath East Africa. Geology, 28, 599-602.

Phipps Morgan, J. 1987. Melt migration beneath midocean spreading centers. Geophysical Research Letters, 14, 1238-1241.

Pilidou, S., Kendall, J.-M., Stuart, G.W. \& BAstow, I.D. 2004. Evidence of melt-induced seismic anisotropy and magma assisted rifting in the Northern Ethiopian Rift. EOS, Transactions of the American Geophysical Union, Fall Meeting Supplement, T33A-1347.

Ritsema, J. \& AI.LEN, R. 2003. The elusive mantle plume. Earth and Planetary Science Letters, 207, $1-12$.

Ritsema, J., Nyblade, A., Owens, T. L.angston, C. \& VANDECAR, J.C. 1998. Upper mantle seismic velocity structure beneath Tanzania, east Africa: Implications for the stability of cratonic lithosphere. Journal of Geophysical Research. $103,21201-21213$.

Ritsema, J., VAN HeiJst, H.-J. \& WoOdhouse, J.H. 1999. Complex shear wave velocity structure beneath Africa and Iceland. Science, 286, $1925-$ 1928.

RoOney, T.O., Furman, T., Yirgu, G. \& Ayelew, D. 2005. Structure of the Ethiopian lithosphere: Evidence from mantle xenoliths. Geochimica and Cosmochimica Acta, 69(15), 3889-3910, doi: $10.1016 / \mathrm{j} / \mathrm{gca} .2005 .03 .043$.

RuMPKer, G. \& RyberG, T. 2000. New 'Fresnel zone' estimates for shear-wave splitting observations from finite difference modelling. Geophysical Research Letters, 27, 2005-2008.

Sandvol, E., Ni, J., Oral.aybey. S. \& Schlue, J. 1992. Shear-wave splitting in the Rio Grande Rift. Geophysical Research Letters, 19, 2337-2340.

Savage, M. 1999. Seismic anisotropy and mantle deformation: What have we learned from shear wave splitting. Reviews of Geophysics, 37, $65-106$

SCHMElling, H. 1985. Numerical models of the influence of partial melt on elastic, inelastic and electric properties of rocks, Part 1: elasticity and anelasticity. Physics of the Earth Planetary Interiors, 41, $34-57$.

Sebai, A., Stutzmann, E., Montagner, J.-P., SiCiliA, D. \& Beucler, E. 2005. Anisotropic structure of the African upper mantle from Rayleigh and Love wave tomography. Physics of the Earth Planetary Interiors (in press).

SElla, G.F., Dixon, T.H. \& MAO, A. 2002. REVEL: A model for Recent plate velocities from space geodesy. Journal of Geophysical Research, 107(B4), doi: 10.1029/2000JB000033.

SHACKLETON, R.M. 1986. Precambrian collision tectonics in Africa, In: CowARD, M.P. \& RIFS, A.C. (eds) Collision Tectonics. Geological Society, London, Special Publications, 19, 329349.

Silver, P.G. 1996. Seismic anisotropy beneath the continents. Anmual Reviews of Earth and Planetary Sciences, 24, 385-432. 
Silver, P.G., GaO, S.S., Lil, K.H. \& the Kaapvaal working group 2001. Mantle Deformation beneath Southern Africa. Geophysical Research Letters, 28, 2493-2496.

SLEEP, N.H. 1997. Lateral flow and ponding of starting plume material. Joumal of Geophysical Research, 102, $10001-10012$.

Sleep, N.H., Ebinger, C.J. \& Kendal.l, J.-M. 2002. Deflection of mantle plume material by cratonic keels. In: Fowl.tr, C.M.R., EBINGier, C.J., \& HAWKHSWOR'TH, C.J. (eds) The Early Earth: Physical, Chemical and Biological Development. Geological Socicty, London Special Publications, $199,135-150$.

Stern, R.J., Nielsen, K.C., Best, E., Sultan, M., ARvidson, R.E. \& Krontr, A. 1990. Orientation of the late Precambrian sutures in the ArabianNubian Shield. Geologv, 18, 1103-1106.

TANDON, G.P. \& WENG, G.J. 1984. The effecl of aspect ratio of inclusions on the elastic properties of unidirectionally aligned composites. Polymer Composites, 5, 327-333.

Tiberi, C., Ebinger, C., Ballu, C., Stuart, G.W. \& Olcma, B. 2005. Inverse models of gravity data from the Rea Sea - Gulf of Aden - Ethiopian rift triple junction zone. Geophysical Journal International, 163, 775-787.

Tommasl, A. 1998. Forward modelling of the development of seismic anisotropy in the upper mantle. Earth and Planterary Science Letters, 160, 1-13.

Valchez, A., \& Garridoo, C. 2001. Seismic properties of an Asthenospherized lithospheric mantle: constraints from the lattice preferred orientation of peridotite minerals in the Ronda Massif. Earth and Planetary Science Letters, 192. 235-249.

Vauchez, A., Barruol, G. \& TOMmasi, A. 1997. Why do continents break-up parallel to ancient orogenic belts? Terra Nova, 9, 62-66.
Valchez, A.. Tommasi, A., Barruol, G. \& Maumls, J. 2000. Upper mantle deformation and seismic anisotropy in continental rifts. Physics and Chemistry of the Earth, 25, 111-117.

Vauchez, A., Dineur, F. \& Rudnick, R. 2005. Microstructure, texture and seismic anisotropy of the lithospheric mantle: Insights from the Labait volcano xenoliths (Tanzania). Earth and Planetary Science Letters, 232, 295-314.

WAlKer, K., Nyblade, A.A., Ki.emperer, S.L., BokelmanN, G.H. R. \& Ow'HN, T.J. 2003. On the relationship between extension and anisotropy: Constraints from shear wave splitting across the East Africa Plateau. Journal of Geophysical Research, 109, doi: 10.1029/2003JB002866.

Whertratne, D.S., Forsyth, D.W., Fischer, K.M. \& NyBLADE, A.A. 2003. Evidence for an upper mantle plume beneath the Tanzanian craton from Rayleigh wave tomography. Joumal of Geophysical Research, 108, doi:10.1029/2002JB002273.

Wessel, P. \& SmITh, W.H.F. 1998. New, improved version of generic mapping tools released. Eos: Transactions of the American Geophysical Union, 79, 579 .

Whaler, K. \& HaUtot, S. 2006. The electrical tesistivity structure of the crust bencalh the Northern Ethiopian Rift. In: YIRGL, G. EBINGFR, C. \& MagulRe, P.K.H. (eds) The Afar Volcanic Province within the East African Rift System. Geological Society. London, Special Publications, 259, 293-305.

Wolfe, C.J. \& SolomoN, S.C. 1998. Shear-wave splitting and implications for mantle flow bencath the MELT region of the East Pacific Rise. Science, 280, 1230-1232.

Woiffinden, E., Ebinger, C.. Yirgu, G., Dinno, A. \& AYELEW, D. 2004. Evolution of the northern Main Ethiopian Rift: birth of a triple junction. Earth and Planetary Science Letters, 224, $213-228$. 